\title{
Kesantunan Kritik Sosial dalam Rubrik Parodi di Surat Kabar Kompas
}

\author{
Nuring Wahyu Bayu Ratri ${ }^{1)}$ \\ Universitas Indraprasta PGRI \\ Jalan Nangka No. 58 C/TB. Simatupang, Tanjung Barat, Jakarta Selatan 12530 \\ Apsanti Djokosujatno ${ }^{2)}$ \\ Universitas Indraprasta PGRI \\ Jalan Nangka No. 58 C/TB. Simatupang, Tanjung Barat, Jakarta Selatan 12530 \\ Bambang Sumadyo ${ }^{3)}$ \\ Universitas Indraprasta PGRI \\ Jalan Nangka No. 58 C/TB. Simatupang, Tanjung Barat, Jakarta Selatan 12530
}

\begin{abstract}
This research aims at explaining content and targets of social critics and elaborating politeness manifestation in social critics that was written by Samuel Mulia in Parody Column. The research hypothesis is the fact that Samuel Mulia has a typical style in delivering social critics to society. The social critics delivered by him have met the principles of politeness. This research is conducted by using critical discourse analysis method. The object of the research is social issues contained in the Parody Column. There are two approaches used to analyze the data. First, critical discourse analysis approach by Fairclough and Teun A. van Dijk. Second, pragmatic approach, which is politeness principles by Geoffrey N. Leech (1983). The result of hypothesis testing is obtained by some conclusions as follows: 1) Samuel Mulia as the writer is trying to discuss social issues, such as environmental concerns, classification of classes in society that causes power domination in society. 2) Social criticism delivered with a way to make himself as the object and also subject of the composition. 3) The target of his compositions is explicitly aimed to himself. However, the writer also strays to the society who read his Parody column, especially to them who have positions, wealth, and powers. 4) Samuel Mulia gives the example of social critics that do not offend other parties, so they don't hurt the feelings because of being cornered and judged. Samuel uses ways to criticize other people by using analogy 5) These critics are not enough only by using analogy or metaphor. Every sentence chosen and used to criticize must fulfill wisdom maxims, generosity, appreciation, simplicity and sympathy. 6) Samuel could be said as a polite criticizer. Although, Samuel Mulia, himself, and others admit that he has a critical and sharp voice, Samuel is able to show that he could control himself.
\end{abstract}

Keywords: Social critics, Politeness, Theories from Norman Fairclough and Teun A. van Dijk.

\begin{abstract}
Abstrak
Penelitian bertujuan menjelaskan isi dan sasaran kritik sosial dan menguraikan manifestasi kesantunan dalam kritik sosial yang disampaikan Samuel Mulia pada rubrik Parodi. Hipotesis penelitian tersebut adalah Samuel Mulia memiliki gaya yang khas dalam menyampaikan kritik sosial kepada masyarakat. Kritik sosial yang disampaikan memenuhi prinsip-prinsip kesantunan. Penelitian dilakukan dengan metode analisis wacana kritis. Objek penelitian adalah masalah sosial yang tertuang dalam rubrik Parodi. Ada dua pendekatan yang digunakan untuk menganalisis data. Pertama, pendekatan analisis wacana kritis milik Fairclough dan Teun A. van Dijk. Kedua, pendekatan pragmatik, yaitu prinsip kesantunan Geoffrey N. Leech (1983). Hasil pengujian hipotesis diperoleh simpulan sebagai berikut: 1) Samuel Mulia sebagai penulis mencoba
\end{abstract}




\section{Diskursus: Jurnal Pendidikan Bahasa Indonesia}

Vol. 4, No. 1, April 2021, pp. 56-66

p-ISSN: $2615-4935$

e-ISSN: 2615-4943

mengangkat masalah sosial, seperti peduli lingkungan, adanya pembagian kelas-kelas dalam masyarakat yang juga menyebabkan adanya dominasi kekuasaan dalam masyarakat. 2) Kritik sosial disampaikan dengan cara menjadikan dirinya sebagai objek tulisan sekaligus subjek tulisan. 3) Sasaran tulisannya jelas secara eksplisit ditujukan kepada dirinya sendiri. Namun, sebenarnya penulis juga menyasar masyarakat pembaca Parodi, khususnya mereka yang memiliki jabatan kekuasaan, kekayaan, atau kekuatan besar. 4) Samuel Mulia memberikan contoh kritik sosial yang tidak menyinggung pihak lain sehingga tidak melukai perasaan karena merasa disudutkan atau dihakimi. Samuel menggunakan cara mengkritik pihak lain dengan cara membuat analogi. 5) Kritikan tidak cukup dengan menggunakan analogi atau metafora. Setiap kalimat yang dipilih dan digunakan untuk mengkritik harus memenuhi maksim kebijaksanaan, kedermawanan, penghargaan, kesederhanaan, dan simpati. 6) Samuel dapat dikatakan sebagai pengkritik yang cukup santun. Meskipun dirinya dan banyak orang mengakui bahwa Samuel Mulia memiliki mulut yang tajam dan kritis, namun Samuel mampu menunjukkan bahwa ia dapat mengendalikan dirinya.

Kata Kunci: Kritik Sosial, Kesantunan, Teori Norman Fairclough dan Teun A. van Dijk.

\section{PENDAHULUAN}

Kritik sosial terdiri dari kata kritik dan sosial. Menurut KBBI, kritik bermakna 'kecaman atau tanggapan, atau kupasan kadang-kadang disertai uraian dan pertimbangan baik buruk terhadap suatu hasil karya, pendapat, dan sebagainya.', sedangkan, sosial berarti 'berkenaan dengan masyarakat' (Badan Pengembangan Bahasa dan Perbukuan, 2016). Dengan demikian, dapat disimpulkan bahwa kritik sosial adalah tanggapan yang berisi kecaman pada halhal yang berkaitan dengan masalah sosial, masyarakat.

Dewasa ini kritik menjadi penting dalam tata kehidupan sosial. Saat mengkritik, seseorang dapat memberikan pendapat negatif maupun positif. Akan tetapi, lebih banyak yang mengarahkan pada tanggapan negatif. Saat melakukan kritik, terkadang orang lebih berusaha mengarahkan pada kesalahan yang ada. Kesan menjatuhkan lebih terasa daripada memberikan penilaian yang kerap memberi kritik membangun. Jika hal itu terus terjadi pada lingkup masyarakat maka penilaian akan keburukan yang sering terjadi pada masyarakat akan terus menjadi pembahasan kritik, padahal tidak semua yang terjadi di lingkup masyarakat itu adalah buruk. Hal itu dapat terjadi karena kritik dapat dilakukan oleh siapa saja. Kritik tidak hanya dilakukan oleh mereka yang berkecimpung di bidangnya. Siapa pun boleh mengkritik asal memiliki dasar atas apa yang akan mereka kritik (Seputar Pengetahuan, 2017).

Soekanto (2010: 365) melihat ada delapan masalah sosial yang terjadi di tengah masyarakat, (1) yaitu kemiskinan, (2) kejahatan, (3) disorganisasi keluarga, (4) masalah generasi muda, (5) peperangan, (6) pelanggaran terhadap norma-norma masyarakat, (7) masalah kependudukan, dan (8) masalah lingkungan hidup. Sementara itu, Abdulsyani (2012:188-195) mengemukakan bahwa ada lima masalah sosial utama yang sering terjadi dalam kehidupan masyarakat. Masalahmasalah tersebut, yaitu (1) masalah kriminalitas, (2) masalah kependudukan, (3) masalah kemiskinan, (4) masalah pelacuran (prostitusi), dan (5) masalah lingkungan hidup.

Masalah-masalah sosial tersebut tentu membuat masyarakat jengah dan tidak dapat berdiam diri, melainkan membuat masyarakat tertarik atau terpancing 
untuk menyampaikan kritik. Ada banyak cara yang bisa dilakukan untuk menyampaikan kritik, seperti melakukan unjuk rasa, menyebarkan selebaran, atau menyampaikan secara langsung ke institusi resmi, tetapi ada juga yang melakukan dengan cara semaunya sendiri, seperti melakukan aksi perusakan (vandalisme).

Salah satu feature unik, menarik, yang ada dalam surat kabar KOMPAS adalah feature "Parodi" yang ditulis oleh Samuel Mulia. Menurut KBBI (2016), kata parodi berarti 'karya sastra atau seni yang dengan sengaja menirukan gaya, kata penulis, atau pencipta lain dengan maksud mencari efek kejenakaan'. Di dalam bukunya berjudul $A$ Theory of Parodi, Linda Hutcheon (1985:114) mendefinisikan parodi sebagai suatu bentuk tiruan atau imitasi (visual) yang di dalamnya terkandung unsur-unsur ironi. Menurut Sylvie (2011;21), parodi adalah meniru gaya khas seseorang untuk mengolok-olok atai mengkritiki (dalam Dianti dan Herawati, 2014).

Analisis Wacana Kritis (AWK) dapat digunakan untuk melakukan kajian empiris tentang hubungan-hubungan antara wacana dan perkembangan sosial dan kultural dalam domain-domain sosial yang berbeda. Ada lima ciri umum analisis wacana kritis. Pertama, sifat struktur dan proses kultural dan sosial merupakan sebagian linguistik kewacanaan. Kedua, wacana itu tersusun dan bersifat konstitutif. Ketiga, penggunaan bahasa hendaknya dianalisis secara empiris dalam konteks sosialnya. Keempat, fungsi wacana secara ideologis. Kelima, memuat penelitian kritis (Jorgensen dan Louise, 2007: 114-120). Oleh karena itu, analisis wacana kritis dipakai untuk membongkar kuasa yang ada di dalam setiap proses bahasa: batasan-batasan yang diperkenankan menjadi wacana, perspektif yang mesti dipakai, topik yang dibicarakan.

Berikut ini diungkapkan karakteristik penting dari analisis wacana kritis. Pertama, tindakan, tindakan merupakan wacana yang dipahami sebagai sebuah tindakan (action). Seseorang yang berbicara atau menulis bukan ditafsirkan bahwa dia menulis atau berbicara untuk dirinya sendiri, tetapi untuk berinteraksi dan berhubungan dengan orang lain. Wacana dipandang sebagai sesuatu yang bertujuan, misalnya untuk mempengaruhi, mendebat, membujuk.

Kedua, konteks, konteks merupakan analisis wacana kritis mempertimbangkan konteks dari wacana, seperti latar, situasi, peristiwa, dan kondisi. Wacana di sini dipandang diproduksi, dimengerti, dan dianalisis pada suatu konteks tertentu. Analisis wacana juga memeriksa konteks dari komunikasi: siapa yang mengomunikasikan dengan siapa dan mengapa; dalam jenis khalayak dan situasi apa; melalui medium apa; bagaimana perbedaan tipe dari perkembangan komunikasi; dan hubungan untuk setiap masing-masing pihak.

Ketiga, historis, historis yang dimaksud merupakan salah satu aspek penting dalam memahami teks adalah dengan menempatkan wacana itu ke dalam konteks historis tertentu. Karena itu, pada waktu melakukan analisis perlu tinjauan untuk mengerti alasan wacana yang berkembang atau dikembangkan seperti itu, alasan bahasa yang dipakai seperti itu, dsb.

Keempat, kekuasaan, konsep kekuasaan adalah salah satu kunci hubungan antara wacana dengan masyarakat. Seperti kekuasaan laki-laki dalam wacana menganalisis seksisme, kekuasaan berbentuk dominasi pengusaha kelas atas kepada bawahan. Aspek kekuasaan penting dikritisi untuk melihat apa yang disebut 
kontrol. Sering kelompok dominan lebih mempunyai akses seperti pengetahuan, uang dan pendidikan dibandingkan dengan kelompok tidak dominan.

Kelima, ideologi, ideologi merupakan konsep yang sentral dalam analisis wacana kritis karena teks, percakapan, dan lain-lain adalah bentuk dari praktik ideologi atau pencerminan dari ideologi tertentu. Teori klasik mengatakan bahwa ideologi dibangun oleh kelompok dominan dengan tujuan untuk mereproduksi dan melegitimasi dominasi mereka.

Keenam, representasi, representasi adalah produksi makna atau konsep yang kita pahami melalui bahasa, kode, dan gambar. Representasi menghubungkan konsep dan bahasa yang membuat kita mengacu pada objek, peristiwa atau orang di dunia nyata. Representasi bisa dimaknai mendeskripsikan gambaran atau imajinasi dalam pikiran kita atau merepresentasikan hal lain. Dalam hal ini bahasa merupakan sistem representasi. Ia berfungsi sebagai tanda yang merepresentasikan konsep atau ide kita (Eriyanto, 2001: 6-14 dalam Budiwati, 2011: 301-302).

Ada tiga dimensi Fairclough untuk analisis wacana kritis. Pertama, teks (tuturan, pencitraan visual atau gabungan antara tuturan dan pencitraan). Analisis teks dipusatkan pada ciri-ciri formal (seperti kosakata, tata bahasa, sintaksis, dan koherensi kalimat). Kedua, praktik kewacanaan atau tatanan wacana. Praktik ini melibatkan pemroduksian teks dan pengonsumsian teks. Ketiga, praktik sosial. Teks atau peristiwa komunikatif dapat membentuk dan dibentuk oleh praktik sosial (Jorgensen dan Louise, 2007: 126-131). Teun A. van Dijk (1998) menyatakan bahwa analisis wacana kritis menganalisis wacana-wacana kritis, seperti wacana politik, ras, gender, kelas sosial, hegemoni.

Parodi merupakan sebuah relasi bentuk atau struktur antara dua teks. Sebuah teks baru dihasilkan dalam kaitan politisnya dengan teks rujukan yang bersifat serius. Parodi dalam postmodernisme merupakan sebuah wacana yang berupaya mempertanyakan kembali subjek pencipta sebagai sumber makna. Parodi menyiratkan suatu upaya berdialog dengan masa lalu dan dengan sejarah. Parodi membangun masa kini dengan merujuk pada seperangkat kode-kode sebagai suatu upaya ideologis. Di dalam parodi terdapat sebuah ruang kritik, untuk mengungkapkan satu ketidakpuasan atau bisa juga sekadar ungkapan rasa humor belaka. Untuk itu, kritik, sindiran, kecaman, plesetan, olok-olok, main-main, seringkali dijadikan sebagai titik awal dari sebuah parodi (dalam Tinarbuko, 2007: $6)$.

Selama lebih dari 30 tahun, Samuel menggeluti dunia industri media dan fashion. Samuel Mulia menjadi konsultan media untuk Jakarta Post, majalah Pesona, majalah Noor, dan Beritagar. Samuel juga menjadi motivator untuk beberapa perusahaan, seperti bank dan brand dunia Louis Vuiton dan Dior. Sejak tahun 2004, Samuel Mulai menjadi kolumnis koran Kompas dengan judul Parodi (Siregar, 2018).

Dalam tulisannya, Samuel Mulia selalu mengangkat masalah sehari-hari dan sering terjadi di sekitar kita. Wacana yang dimunculkan cukup ringan, namun menyentil nurani penulisnya sendiri dan juga pembaca. Samuel mengajak pembaca untuk menyadari perilaku atau karakter dirinya dan mengintrospeksi diri, terutama saat mendengar/ membaca suatu informasi, atau saat berinteraksi dengan orang lain. Pembaca Parodi diajak untuk menyaring/ mencerna segala informasi sehingga saat 
kita berinteraksi dengan orang lain, hal-hal baik dan bermaknalah yang diterima lawan tutur kita. Parodi yang ditulisnya tidak hanya menghibur, tetapi sekaligus menjadi alat autokritik. Bahkan, tidak berhenti pada mengoreksi hati nurani penulis dan pembaca, Samuel Mulia juga memberikan tips atau trik untuk mengatasi masalah yang diangkat.

Konsep yang ditawarkan Samuel Mulia sesuai dengan konsep wacana parodi. Karena ada tendensi kesengajaan untuk mendapatkan kejenakaan atau hiburan, berarti penulis menggunakan gaya bahasa yang tidak lugas.

Melalui setiap tulisannya, Samuel Mulia ingin mengungkapkan bahwa saat berkomunikasi dengan orang lain, ada kemungkinan orang lain (lawan tutur) tidak memahami masalah yang dibicarakan. Dengan demikian, Samuel Mulia harus memahami benar karakter lawan tuturnya. Tidak menutup kemungkinan, penutur harus dapat menggunakan jalan tengah, yaitu dengan menggunakan bahasa yang halus. Secara tidak langsung, penutur menjaga kesopanan/ kesantunan dalam bertutur dan bertindak. Melihat pentingnya kesantunan dalam penyampaian kritik, membuat penulis tertarik untuk mengkajinya dengan lebih mendalam.

\section{METODE}

Objek penelitian dalam tesis ini adalah teks/ wacana parodi dalam rubrik PARODI karangan Samuel Mulia yang diterbitkan surat kabar Kompas setiap hari Minggu. Teks Parodi yang diteliti adalah teks yang hanya diterbitkan pada bulan Juli 2020. Teks Parodi akan dianalisis secara kualitatif deskriptif.

Dalam penelitian ini, peneliti menggunakan dua pendekatan. Pertama, pendekatan analisis wacana kritis milik Fairclough dan Teun A. van Dijk. Kedua, pendekatan pragmatik, yaitu prinsip kesantunan Geoffrey N. Leech (1983) dalam bukunya yang berjudul Principles of Pragmatics.

Dalam penelitian ini, peneliti menjadi instrumen kunci karena peneliti sejak awal mendokumentasikan teks "Parodi", merancang penelitian, mengumpulkan data, dan melaporkan data penelitian. Instrumen pendukung dalam penelitian ini adalah daftar pertanyaan. Berikut ini adalah rincian daftar pertanyaannya.

1. Siapa saja yang menjadi sasaran tulisan "Parodi" tersebut?

2. Apa saja masalah sosial dan budaya yang diangkat Samuel Mulia dalam rubrik Parodi?

3. Bagaimana kritikan Samuel Mulia terhadap masalah yang diangkat?

4. Bagaimana tips disampaikan oleh Samuel Mulia untuk para pembaca?

5. Bagaimana penjelasan teks (peristiwa komunikatif), praktik wacana, dan praktik sosial dalam dua teks Parodi?

6. Bagaimana kesantunan dalam rubrik Parodi bulan Juli 2020?

\section{HASIL DAN PEMBAHASAN}

Wacana yang diteliti dalam penelitian ini adalah wacana tulis dalam surat kabar. Wacana Parodi disajikan dalam bentuk dialog, tetapi kadang juga dalam 
bentuk polilog. Wacana-wacana parodi tersebut akan dianalisis dengan menggunakan Analisis Wacana Kritis.

Analisis wacana mempelajari peraturan-peraturan, konvensi-konvensi dan prosedur-prosedur yang membenarkan dan menentukan tata wacana (discursive practice). Analisis wacana menelusuri secara mendalam segala sesuatu yang dikatakan atau ditulis dalam masyarakat, sistem umum, repertoir dari topik-topik pembicaraan, dan aturan-aturan yang dinyatakan yang mengatur hal yang boleh dikatakan dan hal yang tidak boleh, hal yang bisa diperdebatkan dalam suatu bidang kajian. Aliran ini juga menentukan objek penelusuran secara berbeda, yakni memfokuskan meskipun tidak secara eksklusif, terhadap materi-materi tertulis dalam konteks lembagawi, sosial dan politis. Analisis wacana dalam pengertian ini tidak lebih mementingkan disiplin-disiplin budaya tinggi seperti susastra, filsafat dan sejarah, menggunakan metode-metode analisis isi, naratologi, semiotik dan ideologi kritik untuk mengungkap diskursus/ wacana dalam kehidupan sehari-hari (Purbani, 2005: 9).

Menurut Teuw A. van Dijk dalam Eriyanto (2011: 221) penelitian atas wacana tidak cukup didasarkan pada analisis teks semata karena teks hanya berupa hasil dari praktik produksi teks yang merupakan bentuk proses kognisi sosial, sedangkan kognisi sosial sendiri merupakan bentuk dari pendekatan lapangan psikologi sosial. Pendekatan ini merupakan pendekatan analisis wacana yang menjelaskan struktur dan proses terbentuknya suatu teks. Analisis Teun A. van Dijk menggabungkan tiga dimensi wacana (teks, kognisi sosial, dan konteks sosial) ke dalam kesatuan analisis.

Prinsip kesantunan yang digunakan adalah prinsip yang dikemukakan oleh Leech (1983). Berikut ini penjelasan enam maksim kesantunan.

\section{Maksim Kebijaksanaan (Tact Maxim)}

Orang bertutur yang berpegang dan melaksanakan maksim kebijaksanaan akan dapat dikatakan sebagai orang santun. Jika dalam bertutur, orang berpegang teguh pada maksim kebijaksanaan, ia akan dapat menghindari sikap dengki, iri hati, dan sikap lain yang kurang santun terhadap si mitra tutur.

\section{Maksim Kedermawanan (Generosity Maxim)}

Dengan maksim kedermawanan/ kemurahan hati, para peserta pertuturan diharapkan dapat menghormati orang lain. Penghormatan terhadap orang lain akan terjadi bila orang dapat mengurangi keuntungan bagi dirinya sendiri dan memaksimalkan keuntungan bagi pihak lain.

\section{Maksim Penghargaan (Approbation Maxim)}

Dalam maksim penghargaan dijelaskan bahwa orang akan dapat dianggap santun bila dalam bertutur selalu berusaha memberikan penghargaan kepada pihak lain. Dengan maksim ini, diharapkan agar para peserta pertuturan tidak saling mengejek, saling mencaci, atau saling merendahkan pihak yang lain.

\section{Maksim Kesederhanaan (Modesty maxim)}

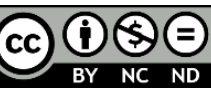


Dalam maksim kesederhanaan atau maksim kerendahan hati ini, peserta tutur diharapkan dapat bersikap rendah hati dengan cara mengurangi pujian terhadap dirinya sendiridan tidak mengunggulkan dirinya sendiri.

\section{Maksim Permufakatan (Agreement Maxim)}

Maksim permufakatan seringkali disebut dengan maksim kecocokan (Wijana, 1996: 59). Dalam maksim ini, ditekankan agar para peserta tutur dapat saling membina kecocokan atau kemufakatan di dalam kegiatan bertutur. Dalam masyarakat tutur Jawa, orang tidak diperbolehkan memenggal atau bahkan membantah secara langsung tuturan orang lain, terutama apabila umur, jabatan, dan status sosial penutur berbeda dengan si mitra tutur.

\section{Maksim Simpati (Sympath Maxim)}

Dalam maksim kesimpatisan, diharapkan para peserta tutur dapat memaksimalkan sikap simpati antar pihak yang satu dengan pihak lainnya. Masyarakat tutur Indonesia sangat menjunjung tinggi rasa simpati terhadap orang lain dalam komunikasi hariannya. Sikap simpati dapat ditunjukkan dengan senyuman, anggukan, atau gandengan tangan (Leech, 1983 dalam Rahardi, 2002: 60-65).

Dalam tulisannya "Webinar" dan "Hidup Baru", Samuel Mulia mencoba mengangkat masalah sosial dan budaya yang ada di Indonesia. Masalah sosial adalah masalah yang terjadi karena ada kesenjangan antara kenyataan dan harapan yang dialami oleh sebagian kecil atau banyak masyarakat kita. Sedangkan, masalah budaya adalah adanya kesenjangan antara nilai yang dianut masyarakat dengan kenyataan.

Dalam teks "Webinar", penulis mengangkat masalah yang dialami seseorang yang diundang dalam webinar dan harus mengikuti kemauan perusahaan sebagai penyelenggara webinar. Samuel Mulia sebagai orang yang sudah berpengalaman dengan pekerjaannya sebagai motivator, mengurusi masalah branding perusahaan, atau mengundang tokoh/ artis yang juga harus mengenali latar belakangnya, ternyata harus mengalah mengikuti permintaan penyelenggara yang berarti dirinya harus menjalankan tugasnya tidak sebagai dirinya sendiri. Karakter dan kepribadian diri yang sesungguhnya dipaksa untuk ditahan dan ternyata semua itu membuat dirinya sangat sedih, bahkan sangat kecewa. Saat ia diundang, dirinya berharap pihak pengundang sudah mengenali karakter dirinya, ternyata hal itu diabaikan. Terlebih lagi ada peserta webinar yang mengiriminya pesan "Mengapa komentar pedasmu tak terasa? Mengapa kamu menjadi orang lain?" Bagi Samuel Mulia, hal ini sama dengan menghancurkan karakter dirinya. Sepertinya masalah "menjadi orang lain" merupakan masalah yang dialami banyak orang. Banyak dijumpai dalam keseharian kita, seseorang terpaksa menjalani pekerjaan yang tidak sesuai dengan kepribadiannya. Misalnya, dia tahu korupsi itu salah dan bertentangan dengan nurani dan agamanya, tetapi tetap dilakukan karena korupsi sudah menjadi mata rantai yang sulit diputuskan. Bila ia tetap mencoba untuk hidup benar, ia sendiri yang akan tersingkir. Untuk menutupi perbuatannya, 
ia melakukan banyak aksi sosial atau aktif di rumah ibadah. Pada akhirnya, orang menjadi terbiasa memiliki kepribadian ganda.

Saat seseorang mengalami peristiwa yang tidak sesuai dengan harapan, pada umumnya seseorang akan marah atau mengeluarkan makian, baik secara verbal atau tertulis (sekarang dituliskan di media sosial). Yang terjadi pada Samuel Mulia justru sebaliknya. Benar ia menceritakan perasaannya, tetapi tidak untuk memaki perusahaan tersebut. Yang terjadi adalah Samuel Mulia dapat menemukan masalah intinya bukan terletak pada harapan yang tidak sesuai dengan kenyataan, melainkan dirinya sendiri yang harus belajar untuk menerima karakter orang lain yang berbeda dengan dirinya. Bahkan, ia sampai pada tahap kesadaran bahwa dirinya yang harus lebih mempersiapkan mentalnya tatkala bertemu dengan orang-orang yang memiliki cara pandang berbeda dengan cara pandangnya.

Demikian pula dengan masalah budaya yang diangkat Samuel Mulia. Samuel Mulia menunjukkan adanya kesenjangan atau ketidaksamaan antara nilai yang yang dianut masyarakat dan kenyataannya. Semua orang atau lembaga tentu akan memilih dengan tepat orang-orang yang terlibat dengan acara atau usahanya. Penyelenggara acara tentu tidak hanya sekadar asal mencari tokoh/ artis/ pembicara yang mempunyai nama. Latar belakang mereka pun perlu dikenali karena ini berkaitan dengan jati diri dan integritas seseorang atau lembaga. namun, yang terjadi adalah sebaliknya. Samuel Mulia merasa bahwa penyelenggara webinar tidak mengenali karakter dirinya yang suka bicara apa adanya, bahkan tajam dalam berbicara/ berkomentar.

Untuk teks kedua "Hidup Baru", Samuel Mulia juga mengangkat masalah sosial dan masalah budaya. Masalah sosial yang diangkat juga dialami oleh banyak orang, yaitu ada keinginan untuk menyapa dengan tulus, tetapi yang terjadi hanya formalitas, basa-basi. Lebih baik melakukan daripada tidak melakukan karena akan berdampak pada penilaian diri. Atau seringnya kita tidak bisa bersyukur, tidak bisa menikmati hal-hal yang dilakukan. Masyarakat, khususnya yang tinggal di perkotaan cenderung untuk menjalani hidup sebagai rutinitas yang harus dijalani. Sehingga, saat aktivitas itu selesai, dirinya tidak bisa mengingat rasanya atau rupanya.

Masalah budaya yang diangkat adalah nilai yang dianut masyarakat selama ini bahwa hidup seseorang dianggap sukses atau mengalami kepenuhan jika memiliki kekayaan atau banyak pengalaman luar biasa. Masalah ini menjadi bentuk sindiran bagi masyarakat Indonesia karena masih banyak dijumpai orang-orang yang menilai seseorang dari harta kekayaan yang dimilikinya. Tidak ada (kalaupun ada, sangat langka) orang yang menilai seseorang sukses atau mengalami kepenuhan ketika dirinya mampu melakukan segala sesuatu dengan penuh kesadaran. Kesadaran di sini tidak hanya berarti dilakukan orang dalam posisi sadar, tidak koma, tetapi lebih pada kemampuan seseorang menyadari setiap hal yang dikerjakannya, saat melangkah, saat menapakkan kaki ke tanah, mampu merasakan nikmatnya menghirup udara bersih, menikmati waktu bersama orang lain, menyadari dan memaknai setiap tulisan yang digoreskan/ diketikkan, dan masih banyak lagi.

Semua masalah sosial dan budaya dalam teks "Webinar" dan "Hidup Baru" yang sebenarnya tidak hanya dialami penulis (Samuel Mulia), disampaikan dengan 
cara halus, bukan dengan marah atau memaki. Meskipun berisi sindiran atau bahkan kritikan terhadap perusahaan penyelenggara webinar, ia menuliskannya sebagai bentuk pertanyaan-pertanyaan tidak habis pikir yang ada di pikirannya atau isi hatinya, Samuel mampu mengangkatnya dengan memperhatikan prinsip kesantunan. Enam maksim kesantunan yang disampaikan Leech telah dipegang dan menjadi prinsip Samuel Mulia saat menulis atau saat ia ada dalam kegiatan bertutur dengan orang lain atau saat beraktivitas bersama orang lain.

Dari masalah yang diangkat, jelaslah bahwa sasaran pembaca teks Parodi ini adalah masyarakat dari kalangan menengah ke atas, baik yang berpendidikan tinggi ataupun tidak. Bila Samuel juga mengulas sedikit tempat tinggalnya yang ada di apartemen, pembaca yang disasar adalah para penghuni apartemen di daerah kota besar. Selama ini orang yang tinggal di apartemen terkenal dengan sikap individualis yang cukup tinggi, mungkin karena banyaknya urusan mereka atau karena mereka merasa sangat mapan sehingga sudah seharusnya orang lain lebih dahulu menyapa dirinya. Samuel Mulia justru menyindir orang-orang demikian. Jika dirinya ingin diperlakukan baik, harus dimulai dari dirinya sendiri, harus menyadari dan merenungkan sudah belumnya seseorang berbuat baik pada orang lain, tidak bisa hanya menuntut.

Semua sindiran atau perenungan yang dikemukakan dengan cara menunjukkan diri penulis yang salah, dapat menjadi tip bagi pembaca. Kesadaran (awareness) baru akan dimiliki seseorang bila dirinya selalu merenungkan, meengevaluasi hidupnya, aktivitasnya, relasinya dengan orang lain. Selain itu, Samuel Mulia memberikan tip agar setiap orang hendaknya memiliki kesiapan mental bila banyak hal terjadi tidak sesuai dengan harapan atau rencana. Di dalam hidup selalu saja ada berbagai kemungkinan atau kegagalan. Penting bagi setiap orang siap secara mental. Kalaupun sampai harus mengalami kegagalan atau kesenjangan, harus disikapi dengan legawa, tidak marah-marah, bahkan sampai memaki orang lain dengan kata-kata kasar. Sebagai orang yang hidup dengan adat timur, kesantunan tetap harus dijunjung tinggi. Manusia tidak dapat melepaskan kodratnya sebagai makhluk sosial yang membutuhkan orang lain. Agar tercipta keharmonisan, sudah sepantasnya seseorang juga harus memegang prinsip kesantunan.

Dari uraian di atas, dapat tampak hal-hal sebagai berikut. Pertama, Samuel Mulia sebagai penulis mencoba mengangkat masalah sosial, seperti peduli lingkungan, adanya pembagian kelas-kelas dalam masyarakat yang juga menyebabkan adanya dominasi kekuasaan dalam masyarakat. Ternyata masalahmasalah sosial tersebut juga muncul dalam kehidupan yang sepertinya terlihat baik, yaitu saat mengadakan acara webinar atau saat menjalani kehidupan dan pekerjaan di rumah akibat adanya PSBB. Masalah-masalah sosial tersebut terjadi dalam kelompok masyarakat yang memiliki budaya sama, bahkan masalah sosial yang diangkat juga berkembang menjadi masalah budaya karena masalah-masalah itu sudah dianggap biasa dan menjadi bagian dari budaya orang perkotaan yang kaya dan padat jadwal pekerjaannya.

Kedua, kritik sosial ini disampaikan penulis Parodi dengan cara menjadikan dirinya sebagai objek tulisan sekaligus subjek tulisan. Dengan teknik penyajian yang digunakan penulis, pembaca Parodi dibuat tidak merasa disalahkan 
melainkan justru dirinyalah yang bersalah, padahal dirinya juga merepresentasikan masalah sosial yang diangkatnya. Meskipun di dalam tulisannya sempat muncul pertanyaan bertubi-tubi yang terkesan menyalahkan, sekali lagi Samuel berhasil mengembalikan pertanyaan itu ke dirinya sendiri. Pertanyaan-pertanyaan kritik yang disampaikan tidak untuk menghakimi orang lain, tetapi dijadikan alat mawas diri Samuel Mulia.

Ketiga, yang menjadi sasaran tulisannya jelas secara eksplisit ditujukan kepada dirinya sendiri. Namun, sebenarnya penulis juga menyasar masyarakat pembaca Parodi, khususnya mereka yang memiliki jabatan kekuasaan, kekayaan, atau kekuatan besar.

Keempat, Samuel Mulia memberikan contoh kritik sosial yang tidak menyinggung pihak lain sehingga tidak melukai perasaan karena merasa disudutkan atau dihakimi. Samuel menggunakan cara mengkritik pihak lain dengan cara membuat analogi, yaitu menggunakan dirinya sendiri sebagai bentuk masalah sosial dan sekaligus solusinya. Kita atau pembaca rubrik parodi dapat mengikuti cara yang digunakan penulis Parodi dalam mengkritik kesalahan seseorang atau suatu institusi.

Kelima, kritikan tidak cukup dengan menggunakan analogi atau metafora. Pemberi kritik harus menyampaikan kritiknya dengan santun. Setiap kalimat yang dipilih dan digunakan untuk mengkritik harus memenuhi maksim kebijaksanaan, kedermawanan, penghargaan, kesederhanaan, dan simpati. Samuel Mulia dapat dikatakan sebagai pengkritik yang santun. Meskipun dirinya dan banyak orang mengakui bahwa Samuel Mulia memiliki mulut yang tajam dan kritis, namun Samuel mampu menunjukkan bahwa ia dapat mengendalikan dirinya, tidak berkata kasar atau merendahkan pihak lain. Semua maksim kesantunan telah menjadi prinsip Samuel Mulia dalam menjalani pekerjaannya dan kehidupannya.

Keenam, Samuel Mulia dapat dikatakan sebagai pengkritik yang cukup santun. Meskipun dirinya dan banyak orang mengakui bahwa Samuel Mulia memiliki mulut yang tajam dan kritis, namun Samuel mampu menunjukkan bahwa ia dapat mengendalikan dirinya, tidak berkata kasar atau merendahkan pihak lain. Semua maksim kesantunan telah menjadi prinsip Samuel Mulia dalam menjalani pekerjaannya dan kehidupannya. Meskipun di dalam tulisannya sempat muncul pertanyaan bertubi-tubi yang terkesan menyalahkan, sekali lagi Samuel berhasil mengembalikan pertanyaan itu ke dirinya sendiri, bukan orang lain yang bersalah, melainkan dirinya. Pertanyaan-pertanyaan itu tidak untuk menghakimi orang lain, tetapi sebagai bentuk mawas diri Samuel Mulia. Selain itu, Samuel Mulia memberikan contoh kritik sosial yang tidak menyinggung pihak lain sehingga tidak melukai perasaan karena merasa disudutkan atau dihakimi. Samuel menggunakan cara mengkritik pihak lain dengan cara membuat analogi, yaitu menggunakan dirinya sendiri sebagai bentuk masalah sosial dan sekaligus solusinya. Kita atau pembaca rubrik Parodi dapat mengikuti cara yang digunakan penulis Parodi dalam mengkritik kesalahan seseorang atau suatu institusi. 


\section{SIMPULAN}

Berdasarkan hasil dan pembahasan, dapat disimpulkan bahwa Samuel Mulia sebagai penulis rubrik/ kolom Parodi di KOMPAS yang notabene sudah terkenal, menguasai banyak bidang, tetap menjaga kesantunan dalam menulis. Sindiran atau kritik-kritik sosial yang diangkat selalu disampaikan dengan gaya yang ringan dan tidak pernah menyalahkan atau menghakimi orang lain. Letak kesalahan bukan pada orang lain, melainkan pada dirinya. Sehingga, dirinya sendiri yang harus menyadari adanya kesalahan dan mencari solusi atas masalah yang terjadi. Masalah tidak dibiarkan begitu saja, selalu ada solusi, dan semuanya selalu dimulai dari dirinya. Dengan kata lain, semua masalah yang diangkat menjadi alat untuk mawas diri dan usaha menjalani hidup dengan benar.

\section{DAFTAR PUSTAKA}

Badan Pengembangan Bahasa dan Perbukuan. (2016). KBBI dalam jaringan (online). Jakarta: Kementerian Pendidikan dan Kebudayaan Republik Indonesia.

Dianti, D. E., \& Herawati, A. (2014). Implementasi konsep kreatif pendekatan parodi dalam iklan televisi Axis. Yogyakarta: Program Studi Ilmu Komunikasi, FISIP, Universitas Atma Jaya Yogyakarta. Dalam http://ejournal.uajy.ac.id/4297/1/Jurnal.pdf).

Jorgensen, M. W., \& Phillips, L. J. (2007). Analisis wacana: Teori dan metode. Yogyakarta: Pustaka Pelajar.

Kompasiana. (2015). Analisis wacana kritis. Diaksesn dari https://www.kompasiana.com/analisis_wacana/54f95c4ca3331169018b4d c8/analisis-wacana-kritis.

Purbani, W. (2005). Analisis wacana/ discourse analysis. Lokakarya Penelitian di UBAYA, Surabaya, 28 Januari 2005 (halaman 9). Diakses dari http://staffnew.uny.ac.id/upload/131874171/pengabdian/discourseanalysis.pdf 28 Januari 2005.

Rahardi, K. (2002). Pragmatik: Kesantunan imperatif bahasa Indonesia. Jakarta: Erlangga.

Seputar Pengetahuan. (2017). Pengertian kritik sosial dan kedudukannya sebagai bahasa (Lengkap). dalam https://www.seputarpengetahuan.co.id/2017/03/ pengertian-kritik-sosial-dan-kedudukannya-sebagai-bahasa.html.diakses 19 Oktober 2020.

Siregar, I. (2018). Samuel Mulia. dalam http://litera.id/2018/08/03/samuel-mulia/3 Agustus 2018.

Soekanto, S. (2010). Sosiologi suatu pengantar. Jakarta: Rajawali Pers.

Tinarbuko, S. (2007). Eksekusi iklan televisi dengan pendekatan parodi. Jurnal Ilmu Komunikasi, IV, (1). Diakses dari https://media.neliti.com /media/publications/137266-ID-eksekusi-iklan-televisi-dengan-pendekata. pdf. 